\title{
Potassium Metabolism in Rats Refed a Lysine-excess Diet after Starvation
}

\author{
Noriko Hisanaga, Yoritaka Aoyama* and Akira Yoshida \\ Laboratory of Nutritional Biochemistry, Department of Agricultural Chemistry, \\ School of Agriculture, Nagoya University, Furo-cho, \\ Chikusa-ku, Nagoya 464-01, Japan \\ Received September 18, 1989
}

\begin{abstract}
Rats starved for 3 days were refed a lysine-excess diet for $3,5,7,10$, and 15 days, and then examined for changes in potassium levels in the urine, gastrocnemius muscle, liver, serum, and intestine. The urinary excretion of potassium was markedly raised for 2 days after the start of refeeding on the lysine-excess diet, but more prolonged refeeding had little or no effects on the urinary excretion of potassium. The potassium content in the gastrocnemius muscle after refeeding for 3,5 , or 10 days was lower in the lysine-excess group than in the basal group, although that in the liver was significantly higher in the lysine-excess group after refeeding for 3 or 7 days. No changes in the potassium content in the gastrocnemius muscle were observed after refeeding for 15 days, while the serum potassium was lowered in rats refed the lysine-excess diet for 5 or 7 days. The sodium contents in the urine and some organs tested were almost unchanged irrespective of lysine loading throughout the experimental period, with a few exceptions. Thus, these results indicated that refeeding on excess lysine caused a transient increase in the urinary potassium excretion, suggesting that most of the potassium would have been released from the muscle.
\end{abstract}

Standerfer and Handler ${ }^{1 \prime}$ first showed that orotic acid intake induced fatty liver. Arginine deficiency and lysine-excess also resulted in fatty liver and orotic aciduria. ${ }^{2-8)}$ Addition of adenine, allopurinol, corn oil, or arginine to these diets prevented the production of fatty liver. $^{2-4,7-10)}$

Dickerman and Walker ${ }^{11}$ have demonstrated that infusion of excess lysine into dogs increases urinary potassium excretion. Jones et $a l^{12)}$ have reported that a transient increase in the urinary potassium excretion is observed in rats after replacement of a basal diet by a lysine-excess diet as compared with those given a lysine-excess diet for 5 weeks. But the urinary potassium levels in rats fed a basal diet was similar to that in rats during the transition to a lysine-excess diet from a basal diet. ${ }^{12)}$ Recently, Aoyama et al. ${ }^{13,14)}$ have reported that refeeding a lysine-excess diet for 7 days to starved rats results in lipid accumulation in the liver and that a significant increase in urinary potassium excretion is observed for the first two days after refeeding the lysine-excess diet.

These studies deal with changes in the potassium levels in the muscle, liver, serum, and small intestine of rats refed on a lysine-excess diet, which have shown a significant increase in their urinary potassium excretion.

\section{Materials and Methods}

Male rats of the Wistar strain (Shizuoka Laboratory Animal Center, Hamamatsu, Shizuoka, Japan) were housed individually in screen-bottomed cages in an airconditioned room at a temperature of approximately $23^{\circ} \mathrm{C}$. Light was regulated so as to provide equal periods of light $(08: 00-20: 00 \mathrm{hr})$ and dark $(20: 00-08: 00 \mathrm{hr})$. The compositions of the experimental diets are shown in Table I. For the lysine-excess diets, 5\% L-lysine hydrochloride was added to the basal diet at the expense of corn starch. The animals had free access to food except for starvation periods and to water. Rats previously adapted to the basal diet for 3-5 days were starved for 3 days.

The starved rats were refed either the basal diet or the lysine-excess diet for $0,3,5,7,10$, and 15 days. Their body

\footnotetext{
* To whom reprint requests should be addressed.
} 
weights before the beginning of starvation were approximately $130 \mathrm{~g}$.

Urine was collected at the following intervals during the experimental period of 15 days (period $\mathrm{I}$ : days 1 and 2; period II: days 5 and 6; period III: days 9 and 10; period IV: days 14 and 15).

At the end of the experimental period, blood was removed from the heart of the rats, which had been anesthetized with diethyl ether between $09: 30-10: 30 \mathrm{hr}$. Livers and gastrocnemius muscle were immediately excised and weighed. The contents of the small intestine were removed by washing with distilled water. These samples were accomplished by wet ashing with conc. nitric acid

Table I. Composition of ExPERIMENTal DiETs

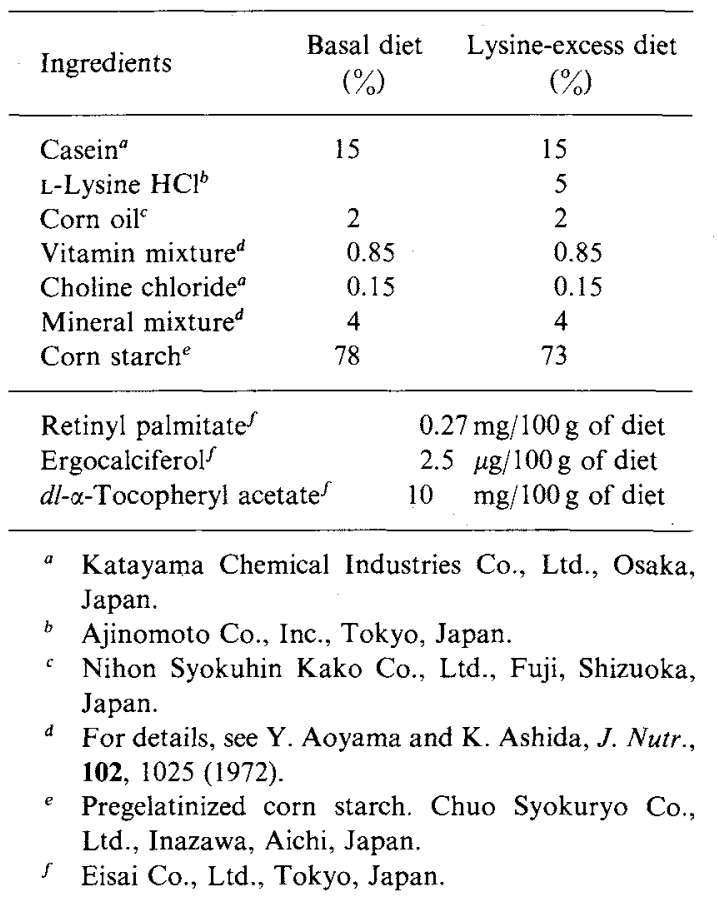

followed by complete digestion with $30 \%$ hydrogen peroxide, ${ }^{15)}$ and the mineral contents were estimated by atomic absorption spectrophotometry ${ }^{16)}$ using certified reference standards. Urinary orotate was measured by the method of Möllering. ${ }^{17)}$

Data were subjected to Student's $t$-test ${ }^{18)}$ to determine whether differences in the means were significant.

\section{Results}

The food intake and body weight gain of rats refed either the basal diet or the lysineexcess diet are summarized in Table II. A decrease in the food intake was observed for rats refed the lysine-excess diet for 3 or 5 days. An addition of excess lysine to the diet significantly decreased the body weight gain through the refeeding period.

The amounts of potassium, sodium, and orotate excreted into the urine are summarized in Table III. The urinary potassium excretion in refed rats increased about two times in period I. In periods II and IV, refeeding the lysine-excess diet did not raise the urinary potassium excretion although a slight increase in its urinary excretion was observed at period III. The urinary sodium excretion was not affected by refeeding the lysine-excess diet except for period III. A significant increase in the urinary orotate excretion was observed in all periods tested. The rats refed the lysineexcess diet excreted much more orotate in periods I and II than in periods III and IV.

The potassium and sodium contents in the gastrocnemius muscle of rats refed either the

Table II. Food Intake and Body Weight Gain of Rats Refed either a Basal Diet or a Lysine-excess Diet

\begin{tabular}{|c|c|c|c|c|c|c|}
\hline \multirow{2}{*}{$\begin{array}{c}\text { Refeeding } \\
\text { period } \\
\text { (days) }\end{array}$} & \multicolumn{2}{|c|}{ Food intake } & \multirow[b]{2}{*}{$p$} & \multicolumn{2}{|c|}{ Body wt gain } & \multirow[b]{2}{*}{$p$} \\
\hline & $\begin{array}{c}\text { Basal } \\
\text { diet } \\
(\mathrm{g} / 3,5\end{array}$ & $\begin{array}{l}\text { Lys-excess } \\
\text { diet } \\
15 \text { days })\end{array}$ & & $\begin{array}{l}\text { Basal } \\
\text { diet } \\
(\mathrm{g} / 3,5,7,\end{array}$ & $\begin{array}{l}\text { Lys-excess } \\
\text { diet } \\
15 \text { days) }\end{array}$ & \\
\hline 3 & $42 \pm 1^{a}$ & $38 \pm 0.4$ & $<0.01$ & $25.2 \pm 1.2$ & $21.0 \pm 1.0$ & $<0.02$ \\
\hline 5 & $74 \pm 0.4$ & $70 \pm 1$ & $<0.01$ & $37.8 \pm 1.9$ & $30.2 \pm 2.0$ & $<0.05$ \\
\hline 7 & $110 \pm 2$ & $107 \pm 2$ & $N S^{b}$ & $50.0 \pm 0.7$ & $39.6 \pm 1.0$ & 0.001 \\
\hline 10 & $174 \pm 2$ & $169 \pm 4$ & NS & $75.4 \pm 1.7$ & $59.0 \pm 2.1$ & 0.001 \\
\hline 15 & $269 \pm 4$ & $269 \pm 5$ & NS & $110.7 \pm 3.1$ & $84.2 \pm 1.7$ & 0.001 \\
\hline
\end{tabular}

a Means $\pm \mathrm{SEM}$ for five rats when refed for 3,5, 7, and 10 days and for six rats when refed for 15 days.

$b$ Not significant. 
Table III. Potassium, Sodium, and Orotate in the Urine of Rats Refed either a Basal or a Lysine-eXcess Diet

\begin{tabular}{|c|c|c|c|c|c|c|}
\hline \multirow{2}{*}{$\begin{array}{c}\text { Period }^{a} \\
\text { collected } \\
\text { urine }\end{array}$} & \multicolumn{2}{|c|}{ Potassium } & \multicolumn{2}{|c|}{ Sodium } & \multicolumn{2}{|c|}{ Orotate } \\
\hline & \multicolumn{2}{|c|}{$\begin{array}{l}\text { Basal diet Lys-excess diet } \\
\text { (meq/ } 100 \mathrm{~g} \text { body wt } / 2 \text { days) }\end{array}$} & \multicolumn{2}{|c|}{$\begin{array}{l}\text { Basal diet Lys-excess diet } \\
\text { (meq/ } 100 \mathrm{~g} \text { body wt/2 days) }\end{array}$} & \multicolumn{2}{|c|}{$\begin{array}{l}\text { Basal diet Lys-excess diet } \\
(\mu \mathrm{eq} / 100 \mathrm{~g} \text { body } w \mathrm{t} / 2 \text { days })\end{array}$} \\
\hline \multirow[t]{2}{*}{ I } & $0.39 \pm 0.02^{b}$ & $0.80 \pm 0.04$ & $3.64 \pm 0.15$ & $3.43 \pm 0.13$ & $2.29 \pm 0.24$ & $35.0 \pm 1.5$ \\
\hline & & .001 & & $\mathbf{S}^{c}$ & & 001 \\
\hline \multirow[t]{2}{*}{ II } & $0.89 \pm 0.05$ & $0.89 \pm 0.01$ & $4.03 \pm 0.12$ & $3.89 \pm 0.06$ & $2.35 \pm 0.20$ & $22.4 \pm 3.0$ \\
\hline & & IS & & S & & 001 \\
\hline \multirow[t]{2}{*}{ III } & $0.84 \pm 0.02$ & $1.09 \pm 0.07$ & $3.88 \pm 0.04$ & $4.81 \pm 0.30$ & $1.66 \pm 0.33$ & $7.50 \pm 0.19$ \\
\hline & & .01 & & .02 & & 001 \\
\hline \multirow[t]{2}{*}{ IV } & $0.85 \pm 0.04$ & $0.89 \pm 0.05$ & $4.07 \pm 0.12$ & $4.70 \pm 0.35$ & $1.21 \pm 0.22$ & $2.54 \pm 0.47$ \\
\hline & & IS & & $\mathrm{S}$ & & \\
\hline
\end{tabular}

a Period I, II, III and IV mean days 1 and 2, days 5 and 6, days 9 and 10, and days 14 and 15, respectively.

b Means \pm SEM for six rats.

c Not significant.

Table IV. Potassium and Sodium in the Gastrocnemius Muscle of Rats ReFed either a Basal or a LySine-eXCess DieT

\begin{tabular}{|c|c|c|c|c|c|c|}
\hline \multirow{3}{*}{$\begin{array}{l}\text { Refeeding } \\
\text { period } \\
\text { (days) }\end{array}$} & \multicolumn{2}{|c|}{ Potassium } & \multirow{3}{*}{$p$} & \multicolumn{2}{|c|}{ Sodium } & \multirow{3}{*}{$p$} \\
\hline & $\begin{array}{c}\text { Basal } \\
\text { diet }\end{array}$ & $\begin{array}{c}\text { Lys-excess } \\
\text { diet }\end{array}$ & & $\begin{array}{c}\text { Basal } \\
\text { diet }\end{array}$ & $\begin{array}{c}\text { Lys-excess } \\
\text { diet }\end{array}$ & \\
\hline & \multicolumn{2}{|c|}{$(\mu \mathrm{eq} / \mathrm{g}$ tissue $)$} & & \multicolumn{2}{|c|}{$(\mu \mathrm{eq} / \mathrm{g}$ tissue $)$} & \\
\hline 0 & \multicolumn{2}{|c|}{$59.6 \pm 2.2^{a}$} & & \multicolumn{2}{|c|}{$26.8 \pm 0.6$} & \\
\hline 3 & $67.5 \pm 1.2$ & $45.9 \pm 2.2$ & $<0.01$ & $26.1 \pm 0.9$ & $27.2 \pm 1.7$ & $\mathrm{NS}^{b}$ \\
\hline 5 & $66.2 \pm 1.8$ & $51.9 \pm 1.5$ & $<0.001$ & $23.4 \pm 0.5$ & $22.8 \pm 0.3$ & NS \\
\hline 7 & $69.4 \pm 4.1$ & $70.2 \pm 2.9$ & NS & $22.0 \pm 1.4$ & $19.7 \pm 0.6$ & NS \\
\hline 10 & $78.0 \pm 1.0$ & $66.9 \pm 0.9$ & $<0.001$ & $22.0 \pm 1.4$ & $24.1 \pm 1.8$ & NS \\
\hline 15 & $64.5 \pm 2.7$ & $69.1 \pm 1.0$ & NS & $28.7 \pm 0.5$ & $31.3 \pm 0.8$ & $<0.05$ \\
\hline
\end{tabular}

a Means \pm SEM for five rats when refed for $0,3,5,7$, and 10 days, and for six rats when refed for 15 days.

b Not significant.

Table V. Potassium and SOdium in the Liver of Rats Refed either a Basal or a Lysine-eXcess Diet

\begin{tabular}{|c|c|c|c|c|c|c|}
\hline \multirow{3}{*}{$\begin{array}{c}\text { Refeeding } \\
\text { period } \\
\text { (days) }\end{array}$} & \multicolumn{2}{|c|}{ Potassium } & \multirow{3}{*}{$p$} & \multicolumn{2}{|c|}{ Sodium } & \multirow{3}{*}{$p$} \\
\hline & $\begin{array}{c}\text { Basal } \\
\text { diet }\end{array}$ & $\begin{array}{c}\text { Lys-excess } \\
\text { diet }\end{array}$ & & $\begin{array}{c}\text { Basal } \\
\text { diet }\end{array}$ & $\begin{array}{c}\text { Lys-excess } \\
\text { diet }\end{array}$ & \\
\hline & \multicolumn{2}{|c|}{ ( $\mu \mathrm{eq} / \mathrm{g}$ tissue $)$} & & \multicolumn{2}{|c|}{ ( $\mu \mathrm{eq} / \mathrm{g}$ tissue $)$} & \\
\hline 0 & \multicolumn{2}{|c|}{$53.0 \pm 1.9^{a}$} & & \multicolumn{2}{|c|}{$40.3 \pm 0.9$} & \\
\hline 3 & $46.2 \pm 1.9$ & $52.3 \pm 1.1$ & $<0.02$ & $31.2 \pm 0.4$ & $32.2 \pm 1.1$ & $\mathrm{NS}^{b}$ \\
\hline 5 & $54.5 \pm 1.5$ & $54.0 \pm 1.1$ & NS & $28.6 \pm 1.0$ & $30.9 \pm 1.1$ & NS \\
\hline 7 & $55.4 \pm 1.6$ & $63.8 \pm 2.6$ & $<0.05$ & $33.4 \pm 0.9$ & $34.6 \pm 1.3$ & NS \\
\hline 10 & $63.3 \pm 1.0$ & $64.3 \pm 1.3$ & NS & $31.5 \pm 1.8$ & $29.6 \pm 0.4$ & NS \\
\hline 15 & $66.3 \pm 1.2$ & $65.8 \pm 2.0$ & NS & $29.4 \pm 0.4$ & $23.0 \pm 0.6$ & NS \\
\hline
\end{tabular}

a Means \pm SEM for five rats when refed for $0,3,5,7$, and 10 days, and for six rats when refed for 15 days.

b Not significant. 
Table VI. Potassium and Sodium in the Serum of Rats Refed either a Basal or a Lysine-excess Diet

\begin{tabular}{|c|c|c|c|c|c|c|}
\hline \multirow{3}{*}{$\begin{array}{l}\text { Refeeding } \\
\text { period }\end{array}$} & \multicolumn{2}{|c|}{ Potassium } & \multirow{3}{*}{$p$} & \multicolumn{2}{|c|}{ Sodium } & \multirow{3}{*}{$p$} \\
\hline & $\begin{array}{c}\text { Basal } \\
\text { diet }\end{array}$ & $\begin{array}{c}\text { Lys-excess } \\
\text { diet }\end{array}$ & & $\begin{array}{l}\text { Basal } \\
\text { diet }\end{array}$ & $\begin{array}{c}\text { Lys-excess } \\
\text { diet }\end{array}$ & \\
\hline & \multicolumn{2}{|c|}{$(\mathrm{meq} / 100 \mathrm{ml})$} & & \multicolumn{2}{|c|}{$(\mathrm{meq} / 100 \mathrm{ml})$} & \\
\hline 0 & \multicolumn{2}{|c|}{$0.41 \pm 0.03^{a}$} & & \multicolumn{2}{|c|}{$13.8 \pm 0.05$} & \\
\hline 3 & $0.34 \pm 0.01$ & $0.32 \pm 0.02$ & $\mathrm{NS}^{b}$ & $13.4 \pm 0.08$ & $13.4 \pm 0.04$ & NS \\
\hline 5 & $0.38 \pm 0.01$ & $0.33 \pm 0.01$ & $<0.01$ & $13.8 \pm 0.04$ & $13.3 \pm 0.08$ & NS \\
\hline 7 & $0.36 \pm 0.01$ & $0.32 \pm 0.01$ & $<0.05$ & $13.4 \pm 0.06$ & $13.8 \pm 0.09$ & NS \\
\hline 10 & $0.36 \pm 0.01$ & $0.33 \pm 0.0 \mathrm{I}$ & NS & $14.0 \pm 0.12$ & $14.6 \pm 0.60$ & NS \\
\hline 15 & $0.38 \pm 0.01$ & $0.40 \pm 0.02$ & NS & $14.4 \pm 0.30$ & $13.9 \pm 0.40$ & NS \\
\hline
\end{tabular}

a Means \pm SEM for five rats when refed for $0,3,5,7$, and 10 days, and for six rats when refed for 15 days.

b Not significant.

basal diet or the lysine-excess diet for $0,3,5,7$, 10 , and 15 days are summarized in Table IV. The potassium content was lower in the lysineexcess group than in the basal group when refed for 3, 5, and 10 days. The potassium content of rats was higher before refeeding than after refeeding the lysine-excess diet for 3 or 5 days. The content of sodium was similar between the two groups except for the values after 15 days' refeeding.

The potassium and sodium contents in the liver of rats refed the experimental diets are summarized in Table V. Refeeding the lysineexcess diet had no effects on the two cation levels in the liver except the increased potassium after refeeding for 3 or 7 days.

The potassium and sodium contents in the serum of rats refed the experimental diets are summarized in Table VI. As a whole, these cation levels in the serum were not affected by the diets even if there are significant minor changes.

There was no difference between the two groups in the potassium and sodium contents in the small intestine (data not shown).

\section{Discussion}

Hevia and Visck, ${ }^{5)}$ and Aoyama et al. ${ }^{7,14\}}$ have reported that lipid accumulation in the liver of rats on a methionine and excess lysine supplemented diet is prevented by the addition of arginine. The nutritional antagonism is characterized by a marked increase in the arginine requirement when dietary lysine concentration is excessive. ${ }^{19)}$ Thus, excess lysine in diet would have caused an arginine deficiency. Growth depression induced by loading with excess lysine was partially ameliorated by the addition of arginine. ${ }^{7,13)}$

The urinary excretion of orotate was markedly raised at early stages after refeeding the lysine-excess diet (Table III), like the previous observation by Ulman et al. ${ }^{8)}$ and might be due to the increased intake of the diet deficient in arginine (a lysine-excess diet) when starved rats were refed, suggesting stimulation of pyrimidine biosynthesis and a concomitant increase in the concentration of orotate in the liver. ${ }^{20)}$

Hevia and Visek, ${ }^{5)}$ and Hevia et al ${ }^{6}{ }^{6}$ have reported that lipids accumulate in the livers of rats fed on a diet supplemented with both methionine and excess lysine for 2 weeks. While Aoyama et al. ${ }^{7}$ have reported that when rats were fed on a lysine-excess diet supplemented with methionine, they did not develop fatty livers. Refeeding of the lysineexcess diet supplemented with methionine for 6 or 9 days, but not for 3 days to the starved rats resulted in the lipid accumulation in the liver. ${ }^{71}$ Aoyama et al. ${ }^{141}$ pursued this further and found that rats refed a lysine-excess diet with or without methionine for 7 days accumulated lipids in the liver. Therefore, in this paper, methionine was not added to the ex- 
perimental diets as shown in Table I.

A marked increase in the urinary excretion of potassium was observed for two days after the beginning of refeeding on the lysine-excess diet (Period I) (Table III) as previously described. ${ }^{13,14)}$ On the other hand, the urinary potassium excretions in periods II and IV were similar between the two groups although the urinary potassium excretion in period III was slightly greater in the lysine-excess group than in the basal group, suggesting that the transient acute hyperkaliuria seen in the rats may have arisen from an initial inability to compensate for the enhanced excretion of potassium. Similar results have been demonstrated by Dickerman and Walker ${ }^{11)}$ who reported that the infusion of lysine into the arteries of dogs increased the urinary potassium excretion. On the contrary, Jones et al. ${ }^{12)}$ showed that the amount of potassium excreted into the urine of rats fed a lysine-excess diet for 5 weeks was lower than that given the basal diet for the same period. Furthermore, they indicated that excess lysine feeding after feeding of a basal diet resulted in markedly increased excretion of potassium as compared with that of a lysine-excess diet for 5 successive weeks.

The serum potassium level was lowered in rats refed the lysine-excess diet for 5 and 7 days (Table VI), as previously observed by Aoyama et al. $^{13)}$ The potassium level in the muscle also decreased in rats refed the lysineexcess diet for 3, 5, and 10 days (Table IV). Such a change in the muscle potassium is compatible with that reported by Jones et al. ${ }^{12)}$ when rats were fed the experimental diets for 14 days. However, in our experiment, no changes in the urinary potassium excretion were observed on days 14 and 15 (period III in Table III), but refeeding the lysine-excess diet for 3 or 7 days increased liver potassium (Table V). The explanation for the decrease in the potassium levels of the serum and muscle may be due to the increased potassium excretion into the uring in periods I and III (Table III), because the skeletal muscle makes up nearly half the body weight of rats. ${ }^{21)}$ The thigh muscle constitute one of the largest of the muscle masses and are also one of the most constant. From its ready availability it furnishes one of the most common sources for muscle samples for chemical analysis.

The urinary potassium excretion was markedly increased after refeeding the lysineexcess diet (Table IV). Dickerman and Walker $^{11)}$ have reported that the infusion of lysine into the arteries of dogs results in extracellular acidosis. Lysine at high concentrations in the muscular cells may have served as a sort of cation in replacement of potassium, thereby leading to the production of alkaline urine and increase bicarbonate excretion, despite the extracellular acidosis. In this connection, Austic and Calvert ${ }^{19}$ ) have postulated that the renal cellular alkalosis arisen from lysine infusion would reduce the kidney's ability to secrete protons and facilitate potassium secretion. Therefore, it is surmised that the oral administration of excess lysine to rats might also have induced kaliuresis by a similar mechanism to that described in dogs with lysine infusion.

\section{References}

1) S. B. Standerfer and P. Handler, Proc. Soc. Exp. Biol. Med., 90, 270 (1955).

2) J. A. Milner, J. Nurt., 109, 663 (1979).

3) Y. Aoyama and K. Ashida, Nutr. Rep. Int., 20, 483 (1979).

4) Y. Aoyama, A. Yoshida and K. Ashida, J. Nutr., 111, 895 (1981).

5) P. Hevia and W. J. Visek, Lipids, 15, 95 (1980).

6) P. Hevia, F. W. Kari, E. A. Ulman and W. J. Visek, J. Nutr., 110, 1224 (1980).

7) Y. Aoyama, K. Sakaida, A. Yoshida and K. Ashida, Brit. J. Nutr., 50, 627 (1983).

8) E. A. Ulman, F. W. Kari, P. Hevia and W. J. Visek, J. Nutr., 111, 1772 (1981).

9) R. E. Handschumacher, W. A. Creasey, J. J. Jaffe, C. A. Pasternak and L. Hankin, Proc. Nat. Acad. Sci. U.S.A., 46, 173 (1960).

10) H. G. Windmueller and L. H. von Euler, Proc. Soc. Exp. Biol. Med., 136, 98 (1971).

11) H. W. Dickerman and W. G. Walker, Am. J. Physiol., 206, 403 (1964).

12) J. D. Jones, R. Wolters and P. C. Burnett, J. Nutr., 89, 171 (1966)

13) Y. Aoyama, T. Nishii, C. Iwata, A. Yoshida and K. Ashida, Nutr. Rep. Int., 30, 287 (1984).

14) Y. Aoyama, T. Nishii and A. Yoshida, Agric. Biol. 
Chem., 53, 2461 (1989).

15) R. M. Forbes, J. W. Erdman, Jr., H. M. Parker, H. Kondo and S. M. Ketelsen, J. Nutr., 113, 205 (1983).

16) Anonymous, Instruction manual, model 170-50A Atomic absorption spectrophotometer, Hitachi Ltd., Tokyo, Japan (1978).

17) H. Möllering, in "Methods of Enzymatic Analysis," Vol. 4, ed. by U. H. Bergmeyer, Academic Press, New York, 1974, pp. 1959.

18) G. W. Snedecor and W. G. Cochran, "Statistical
Methods," Iowa State University Press, Ames., IA, 1967.

19) R. E. Austic and C. C. Calvert, Fed. Proc., 40, 63 (1981).

20) A. S. Hassan and J. A. Milner, Metabolism, 30, 739 (1981).

21) W. O. Cater, J. Poncelet, A. B. Simon and W. D. Armstrong, Proc. Soc. Exp. Biol. Med., 91, 122 (1956). 